\title{
Exhaled nitric oxide measures allergy not symptoms in children with allergic rhinitis in primary care: a prospective cross-sectional and longitudinal cohort study
}

\section{Cindy MA de Bot', *Heleen Moed', Patrick JE Bindels', Roy Gerth van Wijk', Marjolein Y Berger ${ }^{1,3}$, Hans de Groot ${ }^{4}$, Johannes C de Jongste ${ }^{5}$, Johannes $C$ van der Wouden ${ }^{1,6}$}

\footnotetext{
${ }^{1}$ Department of General Practice, Erasmus MC-University Medical Center, Rotterdam, The Netherlands

2 Department of Allergology, Erasmus MC-University Medical Center, Rotterdam, The Netherlands

${ }^{3}$ Department of General Practice, University Medical Center Groningen, University of Groningen, Groningen, The Netherlands

${ }^{4}$ Department of Pediatric Allergology, Reinier de Graaf Groep, Delft, The Netherlands

${ }^{5}$ Department of Pediatric Respiratory Medicine, Erasmus MC-University Medical Center/Sophia Children's Hospital, Rotterdam, The Netherlands

${ }^{6}$ Department of General Practice and EMGO Institute for Health and Care Research, VU University Medical Center, Amsterdam, The Netherlands
}

Originally received 12th April 2012; resubmitted 13th August 2012; revised 17th October 2012; accepted 19th October 2012; online 22nd January 2013

\begin{abstract}
Background: Allergic rhinitis (AR) and asthma are both inflammatory diseases and are often associated. Relationships between fractional exhaled nitric oxide (FeNO) and asthma, atopy, and quality of life have been shown.

Aims: This study aimed to determine whether FeNO in children with $A R(n=158)$ or combined AR and asthma ( $n=93)$ was associated with clinical symptoms, house dust mite (HDM)-specific lgE, and rhinitis-specific quality of life, both cross-sectionally and longitudinally.

Methods: Children with AR aged $6-18$ years $(n=251)$ in primary care were assessed for FeNO, nasal symptom scores, asthma symptom scores, quality of life, and HDM-specific IgE at baseline and 2 years later.

Results: We found similarly elevated FeNO in children with only AR and in those with combined AR and asthma. No correlations were found between FeNO and nasal or asthma symptoms and rhinitis-related quality of life. Longitudinal correlations were strongest for HDM-specific lgE $(r=0.91, p<0.0001)$

Conclusions: FeNO was similar in a selected group of children with AR with and without asthma in primary care and was unrelated to symptoms or quality of life in both groups. FeNO is unlikely to be a useful biomarker of the clinical severity of upper or lower airway disease in primary care.

(C) 2013 Primary Care Respiratory Society UK. All rights reserved.

H Moed et al. Prim Care Respir J 2013; 22(1): 44-50

http://dx.doi.org/10.4104/pcrj.2013.00009
\end{abstract}

Keywords fractional exhaled nitric oxide (FeNO), asthma, allergic rhinitis, child, quality of life

See linked editorial by Gevorgyan and Fokkens on pg 10

The full version of this paper, with online appendix,

is available online at www.thepcrj.org

\section{Introduction}

Allergic rhinitis (AR) and asthma are both inflammatory diseases and are often associated. Asthma is present in $20-50 \%$ of patients with $A R$, and up to $80 \%$ of patients with asthma have AR. ${ }^{1}$ Both conditions are characterised by airway inflammation and blood eosinophilia. ${ }^{2}$ Airway inflammation in asthma and AR involves release of biomarkers including nitric oxide. ${ }^{3}$

Fractional exhaled nitric oxide (FeNO) is a biomarker of eosinophilic airway inflammation. ${ }^{4}$ The measurement of this gas is considered a reliable non-invasive marker of eosinophilic airway

\footnotetext{
* Corresponding author: Dr H Moed PhD, Erasmus MC - University Medical Center Rotterdam, Department of General Practice, Room GK 1051, PO Box 2040, 3000 CA Rotterdam, The Netherlands. Tel: +31-10-7031897 Fax: +31-10-7044766 E-mail: h.moed@erasmusmc.nl
} 
inflammation based on numerous studies that showed an association between the two. ${ }^{5-7}$

FeNO is produced by airway epithelial cells in response to inflammatory cytokines., ${ }^{3,4} \mathrm{~A}$ recent review has shown that FeNO is increased in children with asthma and atopy. ${ }^{8,9}$ One study found a lower quality of life in children with higher NO levels. ${ }^{10}$ Other studies have addressed correlations between FeNO and total IgE or specific IgE to house dust mite (HDM) and positive allergic skin tests. ${ }^{11,12}$

Single measurements of FeNO have been used to assess airway inflammation in asthma and atopy. ${ }^{5,6}$ The usefulness of FeNO in the longitudinal assessment of, for example, asthma control has gained interest in the last couple of years. ${ }^{13,14}$ The recent American Thoracic Society (ATS) guideline on the interpretation of FeNO for clinical applications stated that FeNO could be used as a biomarker that adds a new dimension to the traditional clinical tools in the assessment and management of airway diseases. ${ }^{15}$

The guidelines of the Allergic Rhinitis and its Impact on Asthma (ARIA) Working Group in collaboration with the World Health Organization (WHO) stated that treatment of $A R$ in children and adolescents should focus on achieving patients' well-being by minimising symptoms and improving physical, psychological, and social functioning. Ideally, a combined strategy should be used to treat both upper and lower airway diseases to improve patients' well-being. ${ }^{1}$

As part of a randomised double-blind placebo-controlled trial, the present analysis gave us the opportunity to determine, both crosssectionally and longitudinally, whether FeNO in children with AR only, or with both AR and asthma, was associated with nasal and asthma symptoms, rhinitis-related quality of life, and HDM-specific lgE.

\section{Methods}

\section{Study design}

The present study is a prospective study of a cohort of children with AR derived from an original randomised double-blind placebocontrolled trial comparing the efficacy of 2 years of sublingual immunotherapy (SLIT) plus HDM allergen with placebo in children aged 6-18 years with HDM-related AR in primary care. Within the framework of this study, patients were assessed for FeNO, nose symptom scores, asthma symptom scores, and allergy-related quality of life at baseline and after 2 years. Patients entered the study and started a 2-year treatment with active treatment or placebo. A detailed description of the study design has been published elsewhere. ${ }^{16}$

For the trial we included 251 children who were randomised to either SLIT or placebo treatment. The primary outcome parameter was the mean total nose symptom score (scale 0-12) during the autumn after 2 years of treatment. ${ }^{17}$ Within the study population there was no difference in study outcomes between the two groups after 2 years (see online Appendix, available at www.thepcrj.org). This allowed us to pool the data of both study arms and consider it as a prospective cohort.

The children were subdivided into those with AR only and those with both AR and asthma.

Written informed consent was obtained from parents of all children and assent from children aged 12-18 years. The study was approved by the Ethical Review Board of Erasmus MC University Medical Center Rotterdam.

\section{Patients}

Children aged 6-18 years with at least a 1-year history of AR were invited by their general practitioner (GP) to participate in this study. Children were screened for the following predefined criteria: IgE antibodies $\geq 0.7 \mathrm{kU} / \mathrm{L}$ to HDM (CAP-Phadiatop, Pharmacia Diagnostics $A B$, Uppsala, Sweden); no use of nasal steroids in the month before the start of baseline measurements; retrospective nose symptom score of at least 4 out of 12 points during the last 3 months; and provided written informed consent. Patients who had been treated with immunotherapy in the previous 3 years; had severe asthma; had sensitisation to pets present at home at entry to the study (IgE antibodies $\geq 0.7 \mathrm{kU} / \mathrm{L}$ ); or had a planned surgery of the nasal cavity, were excluded. ${ }^{16}$

\section{Asthma}

The presence of asthma was assessed with the International Study of Asthma and Allergies in Childhood (ISAAC) questionnaire ${ }^{18}$ in case of a positive answer to the following question: "Did you/your child ever have asthma?"

\section{Nasal symptom score in diary}

Four nasal symptoms (rhinorrhoea, blocked nose, sneezing, itching) were scored at baseline and after 2 years. The intensity of these symptoms was subjectively assessed according to a grading scale from 0 to 3 ( $0=$ no complaints, $1=$ minor complaints, $2=$ moderate complaints, $3=$ serious complaints); the maximum score was 12 . The scores were assessed daily by the patient or parents and recorded in a diary. The period of measurement was 1 month at baseline at the beginning of the trial and 3 months after 2 years, both in the period from September to December. The nasal score is a cumulative mean daily nose symptom score measured in a period of 3 months.

\section{Asthma symptom score in diary}

Wheezing/dyspnoea and dry cough during the night were scored in a diary. The intensity of these two symptoms was assessed according to the same grading scale as for nasal symptoms; the maximum score was 6 .

\section{House dust mite-specific $\lg E$}

Serum IgE antibodies to Dermatophagoides pteronyssinus were determined at baseline and after 2 years using the CAP-Phadiatop, according to the manufacturer's instructions. Allergen-specific IgE values of $\geq 0.7 \mathrm{kU} / \mathrm{L}$ (class II) were considered positive.

\section{Quality of life}

Rhinoconjunctivitis-specific quality of life was assessed at baseline and after 2 years using the Dutch version of the Rhinoconjunctivitis Quality of Life Questionnaire (RQLQ). This questionnaire was originally developed and validated in pediatric (6-11 years) and adolescent (12-17 years) patients (PRQLQ and AdoIRQLQ). ${ }^{19,20}$ The questionnaire used at baseline was repeated after 2 years. As we used two different Quality of Life questionnaires for children aged 6-11 years and those aged 12-17 years, we standardised the data by subtracting the mean group score and dividing by the mean standard deviation, enabling us to combine the data for both age groups. 


\section{FeNO}

A single measurement of FeNO was performed at baseline and after 2 years using a hand-held portable nitric oxide analyser (NIOX MINO, Aerocrine $A B$, Solna, Sweden). Participants were asked to inhale to total lung capacity and then exhale through the NIOX MINO at a mouth flow rate of $50 \mathrm{~mL} / \mathrm{s}$ over 10 seconds as per guideline recommendation, assisted by visual and auditory cues. The measurement range of NIOX MINO is 5-300ppb. ${ }^{5,6}$

\section{Statistical analysis}

Analysis was performed using SPSS 17 for Windows (SPSS Inc, Chicago, Illinois, USA). Data from the total group of children were subdivided into children with $A R$ only and those with $A R$ and asthma. The nose and asthma symptom sum scores and HDMspecific IgE values at baseline and after 2 years were square root transformed in order to obtain approximately normal distributions. FeNO measurements were transformed using natural logarithms (In) to obtain a near normal distribution. The strengths of cross-sectional correlation between FeNO, nasal and asthma symptoms, rhinitisrelated quality of life, HDM-specific IgE, and allergy skin testing were assessed using the Pearson correlation coefficient. For the purpose of the analysis, correlation coefficients of $\geq 0.8$ were considered as very strong, $0.6-0.79$ as strong, $0.4-0.59$ as moderate, $0.2-0.39$ as weak, and $<0.2$ as very weak. ${ }^{21}$ The assessment of the longitudinal correlations between baseline and 2 years for FeNO levels, nose and asthma symptoms, rhinitis-related quality of life and HDM-specific IgE were performed by estimating linear regression models. A twosided $p$ value of $<0.05$ was regarded as statistically significant.

\section{Results}

\section{Demographic and clinical characteristics}

The study population consisted of 251 children. The demographic and clinical characteristics of the groups at baseline are presented in Tables $1-3$, which also show the division of the patients into two subgroups. There were 158 children with only AR and 93 children with AR and asthma; $59 \%$ were boys. The mean age of the patients was 11.8 years and $79 \%$ of the patients were multisensitised (Table 1).

Nasal symptoms, asthma symptoms and rhinitisspecific quality of life

The mean nasal symptom score as assessed by diary was 3.2 at baseline and 2.1 at year 2. The mean asthma symptom score was 0.6 at baseline and 0.3 at year 2. Children with combined AR and asthma scored significantly higher on asthma symptoms than those with AR

Table 1. General characteristics of the population subdivided on the basis of only allergic rhinitis (AR) or allergic rhinitis and asthma

\begin{tabular}{lllll} 
& $\begin{array}{l}\text { AR only } \\
(n=158)\end{array}$ & $\begin{array}{l}\text { AR and asthma } \\
(n=93)\end{array}$ & Palue & $\begin{array}{l}\text { Total } \\
(n=251)\end{array}$ \\
\hline Gender (\% male) & $89(56 \%)$ & $60(65 \%)$ & 0.2 & $149(59 \%)$ \\
\hline Mean \pm SD age (years) & $12 \pm 3.1$ & $11.3 \pm 3.0$ & 0.09 & $11.8 \pm 3.0$ \\
\hline Wheeze or dyspnoea in past 12 months (yes) & $62(39 \%)$ & $74(80 \%)$ & $<0.001$ & $136(54 \%)$ \\
\hline Polysensitised (\%) & $121(77 \%)$ & $77(83 \%)$ & 0.3 & $198(79 \%)$ \\
\hline
\end{tabular}

Table 2. Symptoms and rhinitis-related quality of life of the population subdivided on the basis of allergic rhinitis (AR) only or AR and asthma

\begin{tabular}{|c|c|c|c|c|}
\hline & $\begin{array}{l}\text { AR only } \\
(n=158)\end{array}$ & $\begin{array}{l}\text { AR and asthma } \\
(n=93)\end{array}$ & p Value & $\begin{array}{l}\text { Total } \\
(n=251)\end{array}$ \\
\hline Mean \pm SD nasal symptoms at baseline* & $\begin{array}{l}3.2 \pm 1.8 \\
(n=158) \\
\end{array}$ & $\begin{array}{l}3.2 \pm 1.9 \\
(n=93)\end{array}$ & 0.5 & $\begin{array}{l}3.2 \pm 1.9 \\
(n=251)\end{array}$ \\
\hline Mean \pm SD nasal symptoms at year $2^{*}$ & $\begin{array}{l}2.1 \pm 1.7 \\
(n=136)\end{array}$ & $\begin{array}{l}2.2 \pm 1.8 \\
(n=78)\end{array}$ & 0.8 & $\begin{array}{l}2.1 \pm 1.8 \\
(n=214)\end{array}$ \\
\hline Mean \pm SD asthma symptoms at baseline ${ }^{* *}$ & $\begin{array}{l}0.5 \pm 0.9 \\
(n=158)\end{array}$ & $\begin{array}{l}0.9 \pm 0.9 \\
(n=93)\end{array}$ & 0.001 & $\begin{array}{l}0.6 \pm 0.9 \\
(n=251)\end{array}$ \\
\hline Mean $\pm S D$ asthma symptoms at year $2^{* *}$ & $\begin{array}{l}0.2 \pm 0.6 \\
(n=136)\end{array}$ & $\begin{array}{l}0.4 \pm 0.8 \\
(n=78)\end{array}$ & 0.02 & $\begin{array}{l}0.3 \pm 0.7 \\
(n=214)\end{array}$ \\
\hline Mean \pm SD QoL Juniper (standardised) at baseline*** & $\begin{array}{l}-0.1 \pm 0.9 \\
(n=146)\end{array}$ & $\begin{array}{l}0.2 \pm 1.1 \\
(n=86)\end{array}$ & 0.012 & $\begin{array}{l}0.0 \pm 1.0 \\
(n=232)\end{array}$ \\
\hline Mean \pm SD QoL Juniper (standardised) at year $2^{* * *}$ & $\begin{array}{l}0.0 \pm 1.0 \\
(n=133)\end{array}$ & $\begin{array}{l}0.1 \pm 1.0 \\
(n=78)\end{array}$ & 0.5 & $\begin{array}{l}0.0 \pm 1.0 \\
(n=211)\end{array}$ \\
\hline
\end{tabular}

*The intensity of these symptoms (rhinorrhoea, blocked nose, sneezing, itching) was subjectively assessed according to a grading scale: $0=$ no complaints, $1=$ minor complaints, $2=$ moderate complaints, 3=serious complaints; the maximum score was 12 .

** The intensity of these symptoms (wheezing/dyspnoea and dry cough during the night) was subjectively assessed according to a grading scale: $0=$ no complaints, $1=$ minor complaints, $2=$ moderate complaints, $3=$ serious complaints; the maximum score was 6

***Standardised Pediatric Rhinoconjunctivitis Quality of Life Questionnaire (PRQLQ) 6-11 years and Adolescent Rhinoconjunctivitis Quality of Life Questionnaire (AdolRQLQ) 11-17 years. 
Table 3. Measurements of the population subdivided on the basis of allergic rhinitis (AR) only or AR and asthma

\begin{tabular}{|c|c|c|c|c|}
\hline & $\begin{array}{l}\text { AR only } \\
(n=158)\end{array}$ & $\begin{array}{l}\text { AR and asthma } \\
(n=93)\end{array}$ & $\mathrm{p}$ Value & $\begin{array}{l}\text { Total } \\
(n=251)\end{array}$ \\
\hline Median (IQR) FeNO (ppb) at baseline & $\begin{array}{l}34(16-55) \\
(n=151)\end{array}$ & $\begin{array}{l}36(18-55) \\
(n=91)\end{array}$ & 0.94 & $\begin{array}{l}35(17-55) \\
(n=242)\end{array}$ \\
\hline Median (IQR) FeNO (ppb) at year 2 & $\begin{array}{l}34(19-63) \\
(n=136)\end{array}$ & $\begin{array}{l}34(19-59) \\
(n=77)\end{array}$ & 0.78 & $\begin{array}{l}34(19-61) \\
(n=213)\end{array}$ \\
\hline Mean $\pm S D$ HDM-specific lgE $(\mathrm{kU} / \mathrm{L})$ at baseline & $\begin{array}{l}40.2 \pm 36.3 \\
(n=158)\end{array}$ & $\begin{array}{l}55.0 \pm 37.2 \\
(n=93)\end{array}$ & 0.002 & $\begin{array}{l}45.7 \pm 37.3 \\
(n=251)\end{array}$ \\
\hline Mean \pm SD HDM-specific lgE (kU/L) at year 2 & $\begin{array}{l}41.5 \pm 35.9 \\
(n=133)\end{array}$ & $\begin{array}{l}58.4 \pm 33.8 \\
(n=77)\end{array}$ & 0.001 & $\begin{array}{l}47.7 \pm 36.0 \\
(n=210)\end{array}$ \\
\hline
\end{tabular}

only (Table 2). Children with AR only had significantly lower scores on the RQLQ, indicating a better rhinitis-specific quality of life than children with both AR and asthma at baseline $(p=0.01)$ (Table 2).

\section{FeNO and HDM-specific lgE}

FeNO was similarly elevated in children with AR with and without asthma at baseline and after 2 years (median FeNO levels range 34-36ppb, Table 3). Mean HDM-specific IgE was 45.7kU/L at baseline and $47.7 \mathrm{kU} / \mathrm{L}$ at year 2. Children with $A R$ and asthma had significantly higher levels of HDM-specific lgE than children with only AR both at baseline (55.0kU/L) and at year 2 (58.4kU/L).

Cross-sectional correlations between FeNO, nasal and asthma symptoms, and rhinitis-related quality of life No or very weak correlations ranging between 0.147 and 0.192 were found between FeNO levels and nasal symptoms, asthma symptoms, or quality of life in both groups in both years.

\section{Cross-sectional correlation between FeNO and HDM-specific IgE}

A moderate cross-sectional correlation was found between FeNO levels and HDM-specific IgE at baseline $(r=0.404 ; p<0.0001)$ and $a$ weak correlation in year $2(r=0.366 ; p<0.0001)$ in the total group, as shown in Figure 1. Similar results were obtained for children with $A R$ only, with moderate correlations between HDM-specific $\lg E$ and FeNO at baseline $(r=0.441, p<0.0001)$ and year $2 \quad(r=0.448$, $\mathrm{p}<0.0001)$. There was also a weak correlation between HDM-specific $\lg \mathrm{E}$ and FeNO in children with $\mathrm{AR}$ and asthma, but this correlation was only seen at baseline $(r=0.349, p=0.001)$.

FeNO values, nasal and asthma symptoms, rhinitisspecific quality of life and HDM-specific IgE determined longitudinally at baseline and year 2

The longitudinal correlation between FeNO values at baseline and year 2 were moderate $(r=0.597, p<0.0001$; Figure 2$)$. Moderate to strong correlations were seen for nasal symptoms, asthma symptoms, and rhinitis-specific quality of life (Table 4). A very strong correlation was seen for HDM-specific IgE at baseline and at year 2 ( $r=0.911$, $\mathrm{p}<0.0001)$. Similar correlations were seen for FeNO, nasal and asthma symptoms, rhinitis-specific quality of life, and HDM-specific $\lg$ E for children with only AR and for those with combined $A R$ and asthma at baseline and at year 2 (Table 4).

Figure 1. Cross-sectional correlations between fractional expired nitric oxide (FeNO) values and house dust mite (HDM)-specific IgE in the total group $(n=251)$ at $(A)$ baseline and $(B)$ year 2 (Y2) (both $p<0.0001)$. SQRT= square root transformed, In=In-transformed

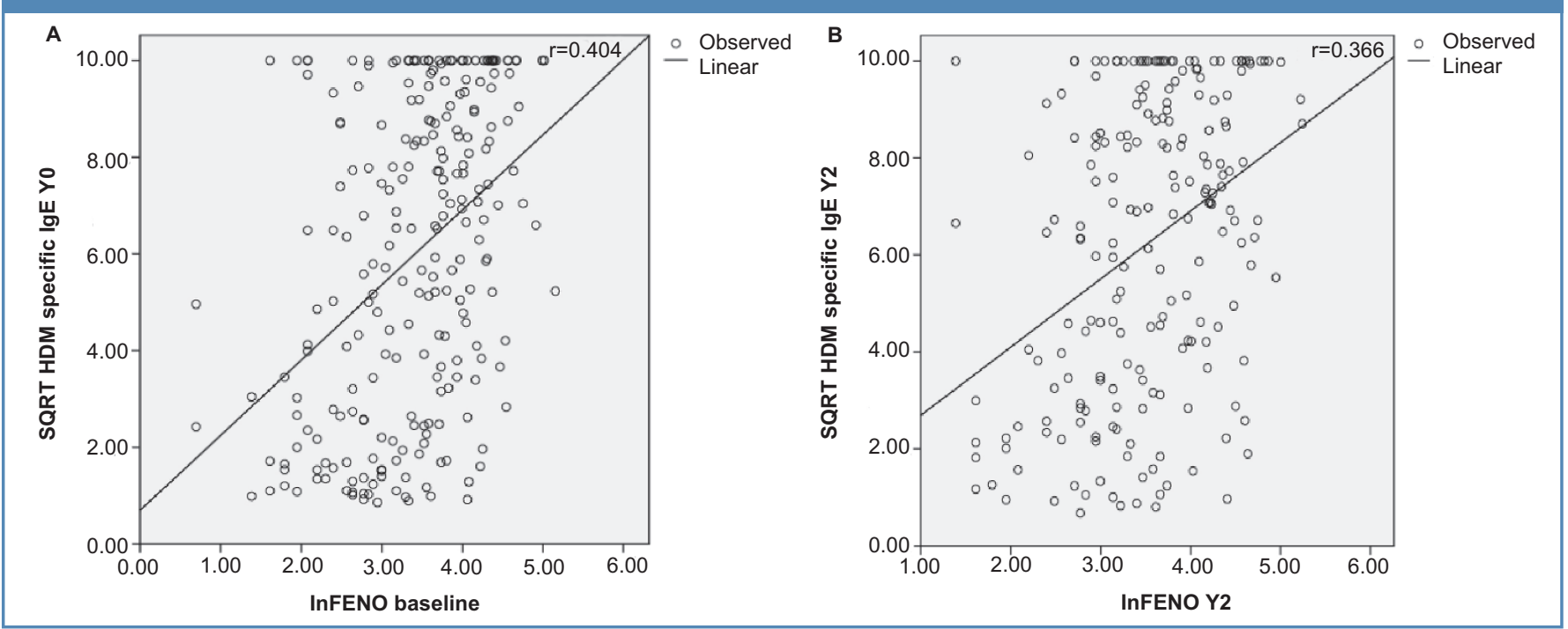


Table 4. Correlation between FeNO values, nasal symptoms, asthma symptoms, rhinitis-specific quality of life and HDM-specific IgE determined at baseline and 2 years later $(Y 2)$

\begin{tabular}{llll} 
& Total group $(n=251)$ & AR only $(n=158)$ & AR and asthma ( $n=93)$ \\
\hline FeNO levels, baseline-Y2 & $\begin{array}{l}r=0.597^{*} \\
(n=213)\end{array}$ & $\begin{array}{l}r=0.642^{*} \\
(n=136)\end{array}$ & $\begin{array}{l}r=0.502^{*} \\
(n=77)\end{array}$ \\
\hline Nasal symptoms, baseline-Y2 & $\begin{array}{l}r=0.611^{*} \\
(n=214)\end{array}$ & $\begin{array}{l}r=0.614^{*} \\
(n=136)\end{array}$ & $\begin{array}{l}r=0.607^{*} \\
(n=78)\end{array}$ \\
\hline Asthma symptoms, baseline-Y2 & $\begin{array}{l}r=0.564^{*} \\
(n=214)\end{array}$ & $\begin{array}{l}r=0.507^{*} \\
(n=136)\end{array}$ & $\begin{array}{l}r=0.575^{*} \\
(n=78)\end{array}$ \\
\hline Rhinitis-specific quality of life, baseline-Y2 & $r=0.442^{*}$ & $r=0.405^{*}$ & $r=0.505^{*}$ \\
& $(n=211)$ & $(n=133)$ & $r=0.894^{*}$ \\
& $r=0.911^{*}$ & $r=0.913^{*}$ & $(n=77)$ \\
\hline HDM-specific IgE, baseline-Y2 & $(n=210)$ & $(n=133)$ & \\
\hline
\end{tabular}

Figure 2. Longitudinal correlation between fractional

expired nitric oxide (FeNO) determined at baseline and 2 years later (total group $n=251, p<0.0001$ ).

In=In-transformed

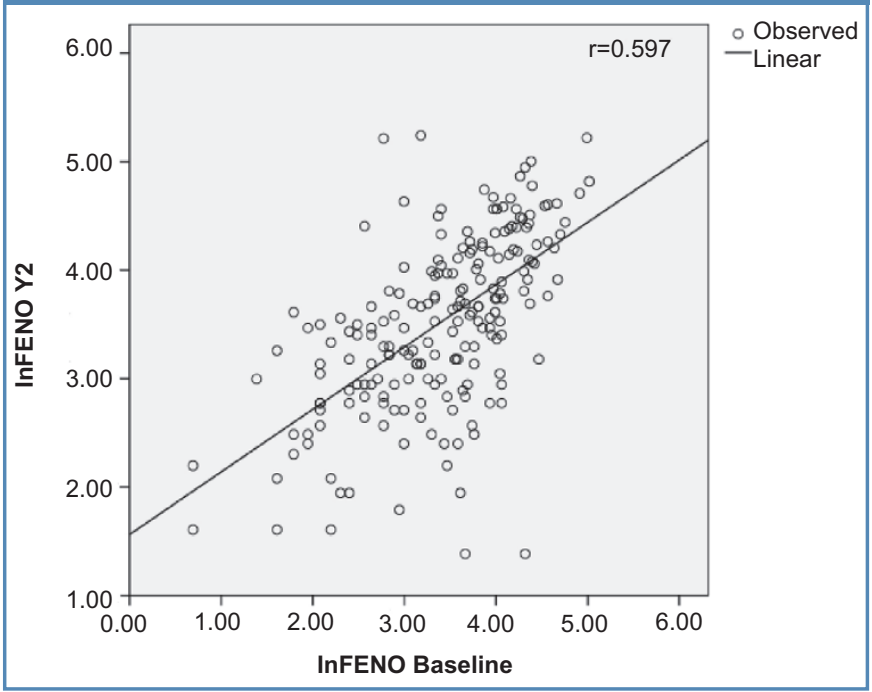

\section{Discussion}

\section{Main findings}

In this primary care paediatric population, all of whom were children with AR who had a positive specific IgE test to HDM, we found similarly increased levels of FeNO in children with AR and combined $A R$ and asthma compared with reference values for healthy children. ${ }^{6.15}$ FeNO was not associated with reported nasal and asthma symptoms, nor with AR disease-specific quality of life in children with AR and HDM allergy. The longitudinal correlations of FeNO, nasal and asthma symptoms, rhinitis-specific quality of life, and HDM-specific IgE were moderate to strong.

\section{Interpretation of findings in relation to previously published work}

Several studies have demonstrated an association between FeNO levels and respiratory symptoms in children. ${ }^{22,23}$ Steerenberg and colleagues reported that wheezing, nasal discharge, and conjunctivitis were positively associated with FeNO levels in atopic children. ${ }^{22}$ However, other studies failed to find a correlation between FeNO and symptoms. ${ }^{11,24}$ Similarly, we found no correlation between FeNO and reported nasal and asthma symptoms. These discrepancies may be explained by the different definitions of, for example, nasal or asthma symptoms, the definition of $A R$, and the heterogeneity of the study populations. Moreover, symptoms depend not only on inflammation but on multiple other mechanisms including the level of perception, and this would obscure any relation with FeNO. It would be advantageous if investigators used standardised definitions and data collection methods for assessing asthma symptom severity or wheeze. ${ }^{25}$

In accordance with others, we found no association between FeNO and the quality of life of children with AR. ${ }^{26}$ However, another study did report a correlation. ${ }^{10}$ This apparent discrepancy can probably be explained by differences in study population and the use of different quality of life questionnaires. On the other hand, in this study we show that children with AR and asthma had a lower rhinitis-specific quality of life score (in addition to asthma symptoms) than children with AR alone, which could be interpreted as more active airway inflammation in these children.

Several studies have demonstrated a positive association between FeNO and total IgE and HDM-specific IgE. ${ }^{11,12}$ The present study also shows a moderate association between FeNO levels and HDM-specific lgE in children with AR and with both AR and asthma. Two studies found that total and HDM-specific IgE levels and blood eosinophilia showed moderate to strong correlations with FeNO..$^{27,28}$ This result suggests that specific lgE-dependent mechanisms are involved in eosinophilic inflammation of the airway in children with atopy and asthma or even in children without allergic sensitisation. ${ }^{27,28}$ Leuppi et al. showed that positive skin prick tests for HDM were associated with raised FeNO. ${ }^{9}$ Cardinale and coworkers concluded that FeNO levels correlated better with total IgE than with positive skin prick tests in children with mild intermittent asthma or AR. However, both markers correlated with FeNO. ${ }^{12}$ These studies indicate that FeNO is a marker of inflammation triggered by allergen exposure.

There is controversy as to whether atopy rather than asthma could explain elevated FeNO levels. The increase in FeNO in nonasthmatic individuals suggests that FeNO reflects allergic 
inflammation of the airways, depending on the degree of atopy. ${ }^{29}$ Malmberg et $a l .^{30}$ suggested that FeNO is a marker of eosinophilic inflammation in asthma, irrespective of the presence of atopy. Franklin et al. stated that elevated FeNO could be associated with atopy but not with doctor-diagnosed asthma. ${ }^{24}$ Other studies did not find differences in FeNO levels between patients with rhinitis or asthma. ${ }^{31,32}$ In our study, we also did not find differences in FeNO between children with AR or AR and asthma. When assessing the relationship between FeNO and asthma or atopy, one must consider that FeNO is a marker of airway inflammation. Asthma and AR are both inflammatory diseases of the airways, and lower airways may exhibit allergic inflammation without symptoms which could be responsible for a possible variation in FeNO. Also, atopy status ${ }^{9}$ and allergen exposure ${ }^{33}$ may affect FeNO levels.

Changes in FeNO measured over time may reflect underlying changes in airway inflammation better than single measurements. ${ }^{15}$ Roberts et al. indicated that levels of FeNO could provide better clinical information when compared with a child's previous FeNO than when compared with a population-based normal range. ${ }^{13}$ Indeed, Van der Valk et al. showed that repeated FeNO measurements could predict asthma exacerbations in children with a lag of 1-2 weeks. ${ }^{14}$ Our time interval of 2 years may be too long to reflect underlying changes in airway inflammation. Also, this population faced major changes in physical development during 2 years which could influence the natural course of asthma and affect FeNO levels.

\section{Implications for future research, policy and practice}

The recent ATS guideline on the interpretation of FeNO for clinical applications stated that FeNO could be used as a biomarker that adds a new dimension to the traditional clinical tools in the assessment and management of airways diseases. ${ }^{15}$ Our results suggest that the role of FeNO measurements in a primary care population of atopic children deserves special attention. We propose that studies are needed to determine how to interpret FeNO measurements in primary care.

\section{Strengths and limitations of this study}

We examined a large group of children with AR in primary care to determine whether FeNO could be a useful measure of upper or lower airway disease severity in children with mild to moderate disease. In the Netherlands, the majority of patients with AR are treated by primary care physicians. We therefore considered it important to perform this analysis in this population. Some aspects of this study may have affected our results. First, the definition of asthma was based on questionnaire data. It might be that a definition based on a doctors' diagnosis of asthma ${ }^{24}$ or on objective measures such as reversibility to $\beta_{2}$-agonist, lung function, or bronchial hyperresponsiveness would be more accurate. However, this higher specificity would unavoidably lead to a much lower sensitivity and loss of many cases. We did not perform multivariate analyses to control for potential confounding effects of inhaled corticosteroid treatment or indoor allergen exposure associated with FeNO as we did not have these data for all the children. Both aspects could have consequences for the generalisability of our findings, but are probably not differential and are therefore unlikely to affect our findings.

\section{Conclusions}

In conclusion, FeNO was similar in a selected group of children with AR with and without asthma in primary care, and was unrelated to symptoms or quality of life in both groups. FeNO was related to specific lgE to HDM at baseline and at 2 years. FeNO is unlikely to be a useful measure of the clinical severity of upper or lower airway disease in children in primary care.

\section{Handling editor Mike Thomas \\ Statistical review Gopal Netuveli}

Conflicts of interest The authors declare that they have no conflicts of interest in relation to this article.

Contributorship $\mathrm{CdB}, \mathrm{HM}$ and JvdW had full access to the data and were responsible for the conception and design of the study as well as interpretation, analysis and writing. PB, RGvW, MB, HdG and JdJ commented on drafts of the manuscript.

Funding This study was funded by Artu Biologicals (since 2010 owned by ALK/Abello), Lelystad, The Netherlands. The trial was registered as ISRCTN91141483 (Dutch Trial Register).

\section{References}

1. Bousquet J, Van Cauwenberge P, Khaltaev N, et al. Allergic rhinitis and its impact on asthma. J Allergy Clin Immunol 2001;108(5 Suppl):S147-334. http://dx.doi.org/ 10.1067/mai.2001.118891

2. Demoly $\mathrm{P}$, Bousquet J. The relation between asthma and allergic rhinitis. Lancet 2006;368:711-13. http://dx.doi.org/10.1016/S0140-6736(06)69263-5

3. Gustafsson LE, Leone AM, Persson MG, et al. Endogenous nitric oxide is present in the exhaled air of rabbits, guinea pigs and humans. Biochem Biophys Res Commun 1991;181:852-7. http://dx.doi.org/10.1016/0006-291X(91)91268-H

4. Alving K, Weitzberg E, Lundberg JM. Increased amount of nitric oxide in exhaled air of asthmatics. Eur Respir J 1993;6:1368-70.

5. American Thoracic Society/European Respiratory Society. ATS/ERS recommendations for standardized procedures for the online and offline measurement of exhaled lower respiratory nitric oxide and nasal nitric oxide. Am J Respir Crit Care Med 2005;171:912-30. http://dx.doi.org/10.1164/rccm.200406-710ST

6. Taylor DR, Pijnenburg MW, Smith $A D$, et al. Exhaled nitric oxide measurements: clinical application and interpretation. Thorax 2006;61:817-27. http://dx.doi.org/ 10.1136/thx.2005.056093

7. Alving K, Malinovschi A. Basic aspects of exhaled nitric oxide. Eur Respir Monogr 2010;49:1-31. http://dx.doi.org/10.1183/1025448x.00028509

8. Scott M, Raza A, Karmaus W, et al. Influence of atopy and asthma on exhaled nitric oxide in an unselected birth cohort study. Thorax 2010;65:258-62. http://dx.doi.org/10.1136/thx.2009.125443

9. Leuppi JD, Downs SH, Downie SR, et al. Exhaled nitric oxide levels in atopic children: relation to specific allergic sensitisation, AHR, and respiratory symptoms. Thorax 2002;57:518-23. http://dx.doi.org/10.1136/thorax.57.6.518

10. Roberts G, Mylonopoulou M, Hurley C, et al. Impairment in quality of life is directly related to the level of allergen exposure and allergic airway inflammation. Clin Exp Allergy 2005;35:1295-300. http://dx.doi.org/10.1111/j.1365-2222.2005.02333.x

11. Strunk RC, Szefler SJ, Phillips BR, et al. Relationship of exhaled nitric oxide to clinical and inflammatory markers of persistent asthma in children. J Allergy Clin Immunol 2003;112:883-92. http://dx.doi.org/10.1016/j.jaci.2003.08.014

12. Cardinale F, De Benedictis FM, Muggeo V, et al. Exhaled nitric oxide, total serum IgE and allergic sensitization in childhood asthma and allergic rhinitis. Pediatr Allergy Immunol 2005;16:236-42. http://dx.doi.org/10.1111/j.1399-3038.2005.00265.x

13. Roberts G, Hurley C, Bush $A$, et al. Longitudinal study of grass pollen exposure, symptoms, and exhaled nitric oxide in childhood seasonal allergic asthma. Thorax 2004;59:752-6. http://dx.doi.org/10.1136/thx.2003.008722

14. Van der Valk RJ, Baraldi RJ, Stern G, et al. Daily exhaled nitric oxide measurements and asthma exacerbations in children. Allergy 2012;67:265-71. http://dx.doi.org/ 10.1111/j.1398-9995.2011.02734.x

15. Dweik RA, Boggs PB, Erzurum SC, et al. An official ATS clinical practice guideline: interpretation of exhaled nitric oxide levels (FeNO) for clinical applications. Am J Respir Crit Care Med 2011;184:602-15. http://dx.doi.org/10.1164/rccm.9120-11ST 
16. de Bot CMA, Moed H, Berger MY, et al. Randomized double-blind placebocontrolled trial of sublingual immunotherapy in children with house dust mite allergy in primary care: study design and recruitment. BMC Fam Pract 2008;9:59. http://dx.doi.org/10.1186/1471-2296-9-59

17. de Bot CMA, Moed $\mathrm{H}$, Berger MY, et al. Sublingual immunotherapy not effective in house dust mite-allergic children in primary care. Pediatr Allergy Immunol 2012;23:150-8. http://dx.doi.org/10.1111/j.1399-3038.2011.01219.x

18. Asher MI, Weiland SK. The International Study of Asthma and Allergies in Childhood (ISAAC). ISAAC Steering Committee. Clin Exp Allergy 1998;28:52-66. http://dx.doi.org/10.1046/j.1365-2222.1998.028s5052.x

19. Juniper EF, Guyatt GH, Dolovich J. Assessment of quality of life in adolescents with allergic rhinoconjunctivitis: development and testing of a questionnaire for clinical trials. J Allergy Clin Immunol 1994;93:413-23. http://dx.doi.org/10.1016/00916749(94)90349-2

20. Juniper EF, Howland WC, Roberts NB, et al. Measuring quality of life in children with rhinoconjunctivitis. J Allergy Clin Immunol 1998;101:163-70. http://dx.doi.org/ 10.1016/S0091-6749(98)70380-X

21. Swinscow TDV. Statistics at Square One. 9th edn. Revised by Campbell MJ. London: BMJ Publishing Group, 1997.

22. Steerenberg PA, Janssen NAH, de Meer G, et al. Relationship between exhaled NO, respiratory symptoms, lung function, bronchial hyperresponsiveness, and blood eosinophilia in school children. Thorax 2003;58:242-5. http://dx.doi.org/ 10.1136/thorax.58.3.242

23. Nordvall SL, Janson C, Kalm-Stephens $\mathrm{P}$, et al. Exhaled nitric oxide in a populationbased study of asthma and allergy in schoolchildren. Allergy 2005;60:469-75. http://dx.doi.org/10.1111/j.1398-9995.2005.00735.x

24. Franklin PJ, Turner SW, Le Souef PN, et al. Exhaled nitric oxide and asthma: complex interactions between atopy, airway responsiveness, and symptoms in a community population of children. Thorax 2003;58:1048-52. http://dx.doi.org/10.1136/ thorax.58.12.1048

25. Reddel HK, Taylor DR, Bateman ED, et al. An official American Thoracic Society/European Respiratory Society statement. Asthma control and exacerbations: standardizing endpoints for clinical asthma trials and clinical practice. Am J Respir Crit Care Med 2009;180:59-99. http://dx.doi.org/10.1164/rccm.200801-060ST

26. Ehrs PO, Sundblad BM, Larsson K. Quality of life and inflammatory markers in mild asthma. Chest 2006;129:624-31. http://dx.doi.org/10.1378/chest.129.3.624

27. Silvestri M, Pistorio A, Battistini E. IgE in childhood asthma: relevance of demographic characteristics and polysensitisation. Arch Dis Child 2010;95:979-84. http://dx.doi.org/10.1136/adc.2009.163667

28. Sacco O, Sale R, Silvestri M. Total and allergen-specific IgE levels in serum reflect blood. Pediatr Allergy Immuno/ 2003;14:475-81. http://dx.doi.org/10.1046/j.09056157.2003.00092.x

29. Jouaville LF, Annesi-Maesano I, Nguyen LT, et al. Interrelationships among asthma, atopy, rhinitis and exhaled nitric oxide in a population-based sample of children. Clin Exp Allergy 2003;33:1506-11. http://dx.doi.org/10.1046/j.13652222.2003.01800.x

30. Malmberg LP, Turpeinen $H$, Rytila $P$, et al. Determinants of increased exhaled nitric oxide in patients with suspected asthma. Allergy 2005;60:464-8. http://dx.doi.org/10.1111/j.1398-9995.2005.00740.x

31. Chawes $\mathrm{BL}$, Bonnelykke $\mathrm{K}$, Kreiner-Moller $\mathrm{E}$, et al. Children with allergic and nonallergic rhinitis have a similar risk of asthma. J Allergy Clin Immunol 2010;126:567-73. http://dx.doi.org/10.1016/j.jaci.2010.06.026

32. van Asch CJ, Balemans WA, Rovers MM, et al. Atopic disease and exhaled nitric oxide in an unselected population of young adults. Ann Allergy Asthma Immunol 2008;100:59-65. http://dx.doi.org/10.1016/S1081-1206(10)60406-1

33. Spanier AJ, Kahn RS, Hornung RW, et al. Environmental exposures, nitric oxide synthase genes, and exhaled nitric oxide in asthmatic children. Pediatr Pulmonol 2009;44:812-19. http://dx.doi.org/10.1002/ppul.21071

\section{Available online at http://www.thepcrj.org}


Appendix: Measurements of the population subdivided on the basis of total group, active treatment and placebo

\begin{tabular}{|c|c|c|c|c|}
\hline & Total group & Placebo & Active treatment & p Value \\
\hline \multicolumn{5}{|l|}{ FeNO levels } \\
\hline Baseline & $\begin{array}{l}40.0 \pm 29.2 \\
(n=242)\end{array}$ & $\begin{array}{l}40.7 \pm 30.4 \\
(n=121)\end{array}$ & $\begin{array}{l}39.2 \pm 28.1 \\
(n=121)\end{array}$ & 0.68 \\
\hline Year 2 & $\begin{array}{l}45.0 \pm 34.7 \\
(n=213)\end{array}$ & $\begin{array}{l}44.9 \pm 35.7 \\
(n=107)\end{array}$ & $\begin{array}{l}45.1 \pm 33.9 \\
(n=106)\end{array}$ & 0.97 \\
\hline \multicolumn{5}{|c|}{ Nasal symptoms } \\
\hline Baseline & $\begin{array}{l}3.2 \pm 1.9 \\
(n=251)\end{array}$ & $\begin{array}{l}3.2 \pm 1.9 \\
(n=126)\end{array}$ & $\begin{array}{l}3.1 \pm 1.9 \\
(n=125)\end{array}$ & 0.71 \\
\hline Year 2 & $\begin{array}{l}2.1 \pm 1.8 \\
(n=214)\end{array}$ & $\begin{array}{l}2.0 \pm 1.7 \\
(n=109)\end{array}$ & $\begin{array}{l}2.3 \pm 1.8 \\
(n=105)\end{array}$ & 0.33 \\
\hline \multicolumn{5}{|c|}{ Asthma symptoms } \\
\hline Baseline & $\begin{array}{l}0.6 \pm 0.9 \\
(n=251)\end{array}$ & $\begin{array}{l}0.6 \pm 0.9 \\
(n=126)\end{array}$ & $\begin{array}{l}0.6 \pm 0.9 \\
(n=125)\end{array}$ & 0.74 \\
\hline Year 2 & $\begin{array}{l}0.3 \pm 0.7 \\
(n=214)\end{array}$ & $\begin{array}{l}0.2 \pm 0.4 \\
(n=109)\end{array}$ & $\begin{array}{l}0.4 \pm 0.8 \\
(n=105)\end{array}$ & 0.11 \\
\hline \multicolumn{5}{|c|}{ Rhinitis-specific quality of life } \\
\hline Baseline & $\begin{array}{l}0.0 \pm 1.0 \\
(n=232)\end{array}$ & $\begin{array}{l}-0.04 \pm 0.9 \\
(n=116)\end{array}$ & $\begin{array}{l}0.03 \pm 1.1 \\
(n=116)\end{array}$ & 0.61 \\
\hline Year 2 & $\begin{array}{l}0.0 \pm 1.0 \\
(n=211)\end{array}$ & $\begin{array}{l}-0.02 \pm 1.0 \\
(n=107)\end{array}$ & $\begin{array}{l}0.02 \pm 1.0 \\
(n=104)\end{array}$ & 0.74 \\
\hline \multicolumn{5}{|c|}{ HDM-specific lgE } \\
\hline Baseline & $\begin{array}{l}45.7 \pm 37.3 \\
(n=251)\end{array}$ & $\begin{array}{l}46.7 \pm 38.8 \\
(n=126)\end{array}$ & $\begin{array}{l}44.8 \pm 35.9 \\
(n=125)\end{array}$ & 0.68 \\
\hline Year 2 & $\begin{array}{l}47.7 \pm 36.0 \\
(n=210)\end{array}$ & $\begin{array}{l}49.2 \pm 37.1 \\
(n=108)\end{array}$ & $\begin{array}{l}46.2 \pm 34.8 \\
(n=102)\end{array}$ & 0.56 \\
\hline
\end{tabular}

Values shown are mean $\pm \mathrm{SD}$. FeNO= fractional exhaled nitric oxide, $\mathrm{HDM}=$ house dust mite. 